\title{
Specific Inhibition of p25/Cdk5 Activity by the Cdk5 Inhibitory Peptide Reduces Neurodegeneration In Vivo
}

\author{
Jeyapriya Raja Sundaram, ${ }^{1,2}$ Charlene Priscilla Poore, ${ }^{1,2}$ Noor Hazim Bin Sulaimee, ${ }^{2,3}$ Tej Pareek, ${ }^{6}$ A.B.M.A. Asad, ${ }^{7}$ \\ Ramamoorthy Rajkumar, ${ }^{2,3,5}$ Wei Fun Cheong, ${ }^{1,2}$ Markus R. Wenk, ${ }^{1,2,4}$ Gavin Stewart Dawe, ${ }^{2,3,5}$ Kai-Hsiang Chuang, \\ Harish C. Pant, ${ }^{8}$ and Sashi Kesavapany ${ }^{1,2}$ \\ ${ }^{1}$ Department of Biochemistry, ${ }^{2}$ Neurobiology and Ageing Program, Centre for Life Sciences, and Departments of ${ }^{3}$ Pharmacology and ${ }^{4}$ Biological Sciences, \\ Yong Loo Lin School of Medicine, ${ }^{5}$ Singapore Institute for Neurotechnology, National University of Singapore, 28 Medical Drive, \#04-21, Singapore 117456, \\ ${ }^{6}$ Department of Pediatrics, Case Western Reserve University, Cleveland, Ohio 44106, 7Singapore Bio-Imaging Consortium, A*STAR, Biopolis, Singapore \\ 138667, and ${ }^{8}$ National Institute of Neurological Disorders and Stroke, National Institutes of Health, Bethesda, Maryland 20892-4479
}

The aberrant hyperactivation of Cyclin-dependent kinase 5 (Cdk5), by the production of its truncated activator p25, results in the formation of hyperphosphorylated tau, neuroinflammation, amyloid deposition, and neuronal death in vitro and in vivo. Mechanistically, this occurs as a result of a neurotoxic insult that invokes the intracellular elevation of calcium to activate calpain, which cleaves the Cdk5 activator p35 into p25. It has been shown previously that the p25 transgenic mouse as a model to investigate the mechanistic implications of p25 production in the brain, which recapitulates deregulated Cdk5-mediated neuropathological changes, such as hyperphosphorylated tau and neuronal death. To date, strategies to inhibit Cdk5 activity have not been successful in targeting selectively aberrant activity without affecting normal Cdk5 activity. Here we show that the selective inhibition of $\mathrm{p} 25 / \mathrm{Cdk} 5$ hyperactivation in vivo, through overexpression of the Cdk5 inhibitory peptide (CIP), rescues against the neurodegenerative pathologies caused by p25/Cdk5 hyperactivation without affecting normal neurodevelopment afforded by normal p35/Cdk5 activity. Tau and amyloid pathologies as well as neuroinflammation are significantly reduced in the CIP-p25 tetra transgenic mice, whereas brain atrophy and subsequent cognitive decline are reversed in these mice. The findings reported here represent an important breakthrough in elucidating approaches to selectively inhibit the $\mathrm{p} 25 / \mathrm{Cdk} 5$ hyperactivation as a potential therapeutic target to reduce neurodegeneration.

\section{Introduction}

Cyclin-dependent kinase 5 (Cdk5) is a pleiotropic prolinedirected protein kinase primarily involved in regulating mammalian CNS development (Dhavan and Tsai, 2001). Deregulation of Cdk5 activity is thought to contribute to the development of pathological hallmarks found in a number of neurodegenerative diseases, such as Alzheimer's disease (AD), Parkinson's disease, and amyotrophic lateral sclerosis (Lau et al., 2002; Nguyen and Julien, 2003; Smith et al., 2003; Cruz and Tsai, 2004). Previous studies have shown the involvement of p25/Cdk5 in the development of AD-like pathology (Patrick et al., 1999; Ahlijanian et al., 2000). This has led to extensive research on the role of aberrant p25/Cdk5 activity in the pathogenesis of neurodegenerative diseases (Otth et al., 2002; Town et al., 2002; Noble et al., 2003; Saito

Received July 27, 2012; revised Oct. 25, 2012; accepted Nov. 2, 2012.

Author contributions: M.R.W., G.S.D., K.-H.C., H.C.P., and S.K. designed research; J.R.S., C.P.P., N.H.B.S., T.P., A.B.M.A.A., R.R., and W.F.C. performed research; J.R.S., T.P., A.B.M.A.A., R.R., G.S.D., K.-H.C., and S.K. analyzed data; J.R.S. and S.K. wrote the paper.

This work was supported by Singapore Ministry of Health National Medical Research Council Grants WBS 183000-179-213 and 184-000-180-213.

Correspondence should be addressed to Dr. Sashi Kesavapany at his present address: GlaxoSmithKline Singapore Research Centre, Biopolis, 11 Biopolis Way, The Helios, \#03-01/02, Singapore 138862. E-mail: sashi.s.kesavapany@gsk.com.

J. R. Sundaram's present address: Department of Pharmacology, NUS, Singapore 117456.

DOI:10.1523/JNEUROSCI.3593-12.2013

Copyright $\odot 2013$ the authors $\quad 0270-6474 / 13 / 330334-10 \$ 15.00 / 0$ et al., 2007). It has been shown previously that development of p25/Cdk5-mediated neuropathological hallmarks has been linked to neuronal death and a subsequent decline in cognitive function in several p25 transgenic (p25Tg) mouse models (Cruz et al., 2003; Muyllaert et al., 2008). It is important to note that the involvement of p25 in $\mathrm{AD}$ is debated by several groups (Takashima et al., 2001; Bian et al., 2002), with some groups unable to find elevated p25 levels in AD samples (Yoo and Lubec, 2001; Tandon et al., 2003). However, mechanistic production of p25 from the Cdk5 activator p35 through the activation of calpain by excitotoxicity and deregulation of calcium homeostasis to produce an aberrant Cdk5 activity have been reported by several groups (Patrick et al., 1999; Lee et al., 2000; Nath et al., 2000).

Previously, the identification of a specific fragment of p35, the Cdk5 inhibitory peptide (CIP), displayed a specific inhibitory effect on p25/Cdk5 activity in vitro, without affecting "normal" p35/Cdk5 activity (Zheng et al., 2002, 2005). To extend these findings in vivo, we developed a Tg mouse that overexpressed CIP constitutively in the forebrain under the direction of the Camk2a promoter. These novel CIP transgenic (CIPTg) mice appeared phenotypically and developmentally normal with normal Cdk5 function. Additionally, CIP, when co-overexpressed with p25 in CIP-p25 tetra transgenic (TetraTg) mice, was able to reduce p25mediated neurodegeneration. Behavioral studies showed improved cognitive performance in TetraTg mice compared with p25Tg mice. Last, our data from magnetic resonance imaging 
(MRI) studies show that the loss of white matter and shrinkage in brain volume in the $\mathrm{p} 25 \mathrm{Tg}$ mice were rescued by CIP expression in TetraTg mice.

This is the first time that $\mathrm{p} 25 / \mathrm{Cdk} 5$ hyperactivity has been targeted in vivo without affecting $\mathrm{p} 35 / \mathrm{Cdk} 5$ activity, therefore not affecting normal neurodevelopment. This study breaks away from the use of ATP analogs to inhibit Cdk5 activity that has been a barrier in the development of Cdk5 inhibitors. The results reported here represent a significant step forward in the in vivo inhibition of the p25/Cdk5 mechanisms involved in neurodegeneration.

\section{Materials and Methods}

Animal handling. All animal experiments were performed according to approved protocols by the Institutional Animal Care and Use Committee of the National University of Singapore.

Generation of CIPTg mice. The CIP transgene with a FLAG-tag sequence and $5^{\prime}-3^{\prime}$ homology arms were generated from the cDNA (p35 pCDNA) by PCR using primers with inbuilt EcoRI restriction sites. This transgene was then cloned together with human ubiquitin promoter (UbiC), loxP-flanked STOP cassette, and PGK-neo selection cassette into the ROSA 26 vector (Ozgene). The entire vector was sequenced to confirm correct assembly. The vector was linearized with AclI and electroporated into W9.5 embryonic stem (ES) cells. ES cells carrying the CIP transgene were microinjected into fertilized C57BL/6 mouse eggs and reimplanted into pseudo-pregnant C57BL/6 females. The resulting chimeras were crossed with $\mathrm{C} 57 \mathrm{BL} / 6$ mice to produce the germ-line founders (129Sv/J transgenic mice; Ozgene). Founders were screened by PCR with specific primers (5'-GTGCCTGGGTGAGTTTCTCT-3', 5' -CATCGTCGTCCTTGTAATCG-3') directed to the FLAG sequence. The germ-line founders were then crossed with Camk2A-CRE transgenic mice [B6.Cg-Tg (Camk2a-Cre) T29-1StI/J] (The Jackson Laboratory) to get the bitransgenic mice (CIPTg mice), which express CIP in the forebrain using the CRE/LoxP recombination system. Furthermore, CIPTg mice were crossed with p25Tg mice (offspring from the mating of C57BL/6-Tg (tetO-CDK5R1/GFP) 337Lht/J (The Jackson Laboratory) with Camk2a transgenic mice B6; CBA-Tg (Camk2a-tTA) 1Mmay/J (The Jackson Laboratory) (Cruz et al., 2003) to get the TetraTg mice that overexpress both the CIP and p 25 genes. Inducible p 25 gene expression was controlled by the tetracycline derivative doxycycline. TetraTg mice and $25 \mathrm{Tg}$ mice in this study were conceived and raised in the presence of doxycycline ( $200 \mu \mathrm{g} / \mathrm{ml}$; Sigma) in drinking water for 6 weeks postnatally to avert any potential developmental consequences from the expression of $\mathrm{p} 25$. Littermates of the same sex were used for comparison whenever possible.

Antibodies. Antibodies used for both Western blot analyses and immunohistochemistry were mouse monoclonal anti-FLAG (1:200; Sigma), rabbit polyclonal anti-Cdk5 (C8, 1:500; Santa Cruz Biotechnology), mouse monoclonal anti-cytosolic phospholipase 2 (cPLA2) (1:200; Santa Cruz Biotechnology), rabbit monoclonal anti-phospho-glycogen synthase kinase-3 $\beta$ (GSK-3 $\beta$ ) (Ser9; 1:1000; Cell Signaling Technology), mouse anti- $\alpha$-tubulin (1:10,000; Sigma), mouse monoclonal anti-GFP (1:500; Roche), mouse monoclonal anti-GFAP (1:1000; Sigma), mouse monoclonal anti-Cd11b (1:200; Millipore), mouse monoclonal antipaired helical filaments (PHF)-tau antibodies (clones AT8 and AT180, 1:100; Pierce), mouse monoclonal anti- $\beta$-amyloid 1-42 (1:100; Millipore), mouse monoclonal anti- $\beta$-amyloid 1-16 (6E10), and anti-cleaved caspase-3 antibody (1:200; Cell Signaling Technology). Secondary fluorescence-conjugated antibodies Alexa Fluor 488 and Alexa Fluor 594 (Invitrogen) were used at 1:200 dilutions for immunohistochemistry. Horseradish peroxidase-conjugated mouse or rabbit secondary antibodies (GE Healthcare) were used at 1:1000 dilutions for Western blot analyses.

Histochemical studies. CIPTg, p25Tg, and TetraTg mice were anesthetized with the mixture of ketamine $(75 \mathrm{mg} / \mathrm{kg})$ and medepomidin $(1$ $\mathrm{mg} / \mathrm{kg}$ ) and transcardially perfused with freshly made $4 \%$ PFA/PBS. Cryostat brain sections of $16 \mu \mathrm{m}$ thickness were collected, and immunofluorescence staining was performed according to our previously published protocol (Sundaram et al., 2012). Thioflavin-S staining was performed as described previously with slight modification (Sun et al., 2002). Sections were stained with $0.05 \%$ thioflavin-S in $50 \%$ ethanol in the dark for 10 min. This step was followed by differentiation in two changes of $50 \%$ ethanol for $10 \mathrm{~s}$ each and two washes in large volumes of distilled water. Confocal images were taken at $40 \times$ magnification. Nissl and Bielschowsky silver staining were performed according to the previously published protocols (Litchfield and Nagy, 2001).

TUNEL staining. TUNEL staining was performed according to the instructions of the manufacturer using the In Situ Cell Death Detection Kit, TMR red (Roche).

Western blot analyses. Brain lysates from CIPTg, p25Tg, and TetraTg mice were prepared as described previously (Kesavapany et al., 2004). Polyacrylamide gel running, nitrocellulose membrane transfer, and detection were performed as reported previously (Sundaram et al., 2012).

$\left[\gamma^{32} P\right] A T P$ kinase assay. Kinase assays to investigate the changes in Cdk5 activity were performed using brain lysates from CIPTg, p25Tg, and TetraTg mice as described in our previous publication (Poore et al., 2010).

Immunoprecipitation and coimmunoprecipitation assay. Immunoprecipitation was performed according to the protocol published previously ((Poore et al., 2010). Briefly, lysates from brain samples of wild-type (WT) and CIPTg mice were precleared with protein G-Sepharose beads (Sigma) for $1 \mathrm{~h}$ at $4^{\circ} \mathrm{C}$. Precleared protein $(500 \mu \mathrm{g})$ was incubated with 10 $\mu \mathrm{g}$ of mouse monoclonal anti-Cdk5 (J3; Santa Cruz Biotechnology) for $3-4 \mathrm{~h}$ at $4^{\circ} \mathrm{C}$, and protein G-Sepharose beads were added to the lysates for overnight incubation at $4^{\circ} \mathrm{C}$. Coimmunoprecipitated proteins were then immunodetected using rabbit polyclonal anti-p35 (C19, 1:500; Santa Cruz Biotechnology) and rabbit polyclonal anti-p39 (1:1000; Cell Signaling Technology) antibodies.

cPLA2 activity assay. cPLA2 activity assay was performed according to the instructions of the manufacturer using cPLA2 Activity Assay Kit (Cayman Chemical). The results were normalized against protein concentration determination by BCA assays (Pierce Biotechnology).

Lipids analysis using HPLC mass spectrometry. Lipid extraction and mass spectrometry was performed as published previously using the brain samples from p25Tg, CIPTg, and TetraTg mice (Sundaram et al., 2012).

MRI. CIPTg, p25Tg, and TetraTg mice underwent MRI to observe the brain morphological changes between different animal groups in vivo. Manganese enhanced MRI was used to enhance contrast of different brain regions for better visualization of cytoarchitecture in anatomical imaging (Aoki et al., 2004). Animals were administered slowly with $0.1 \mathrm{M}$ $\mathrm{MnCl}_{2}$ at a dosage of $80 \mathrm{mg} / \mathrm{kg}$ body weight via intraperitoneal injection with an infusion pump at a rate of $0.25 \mathrm{ml} / \mathrm{h}$. Imaging experiments were performed between 1 and $1.5 \mathrm{~d}$ after the administration of $\mathrm{MnCl}_{2}$ (Aoki et al., 2004; Chuang and Koretsky, 2006). Magnetic resonance images were acquired on a 9.4 tesla scanner with $31 \mathrm{~cm}$ horizontal bore magnet interfaced to Varian console (Agilent Technologies). A 72-mm-innerdiameter volume coil (Rapid Biomedical) was used for the transmission of radio frequency wave, and a custom-designed $15 \mathrm{~mm}$ single-loop surface coil was placed on the animal's head as the receive coil. Images were acquired using T1-weighted 3D magnetization-prepared rapid acquisition with gradient echo sequence with the following: repetition time, $8 \mathrm{~ms}$; echo time, $2.60 \mathrm{~ms}$; flip angle, $10^{\circ}$; inversion time, $1.0 \mathrm{~s}$; matrix size, $256 \times 192 \times 128$; and field of view, $25.6 \times 19.2 \times 12.8 \mathrm{~mm}^{3}$. Nine averages were acquired in $90 \mathrm{~min}$ to increase signal-to-noise ratio. The images were then zero filled and reconstructed to a matrix size of $256 \times 256 \times 128$, resulting in a final resolution of $0.1 \times 0.075 \times 0.1$ $\mathrm{mm}^{3}$.

Radial maze. The radial arm maze paradigm was performed as reported previously (Zou et al., 1998; Schmitt et al., 2003), with slight modifications mentioned below. The maze consisted of eight arms, numbered from 1 to 8 , extending radially from the central area $(5 \mathrm{~cm}$ lane width $\times 35 \mathrm{~cm}$ arm length $\times 9 \mathrm{~cm}$ wall height; Stoelting ANY-maze). Visual cues (black and white images) were placed in the arms 2, 4, 6, and 8 (at the end of each arm). In the training phase, mice were given $7 \mathrm{~min}$ to explore all the arms and eat the novel food (fruit loops) that were placed in only one arm in the order of $2,4,6$, or 8 each session. The apparatus 
A

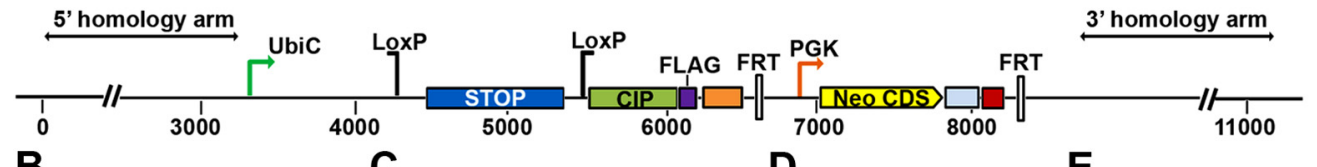

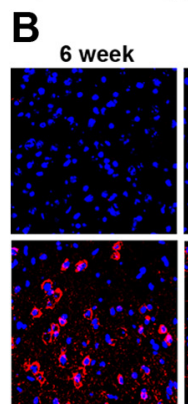

F

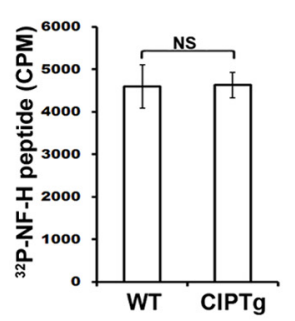

C

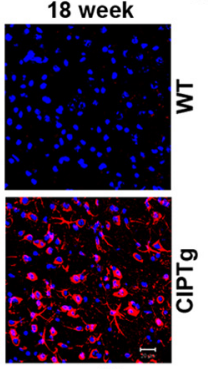

G

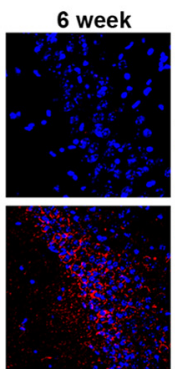

Input IP-Cdk5 (J3)

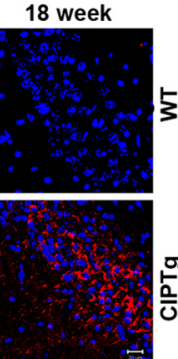

H
D

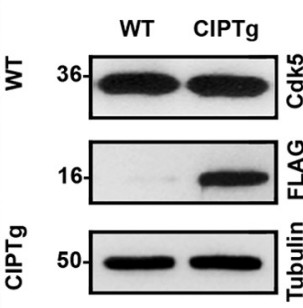

E

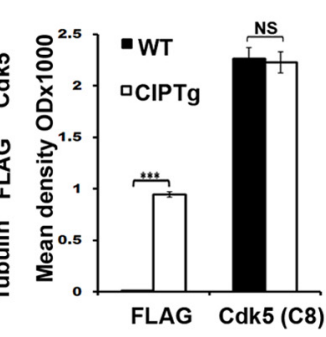

I
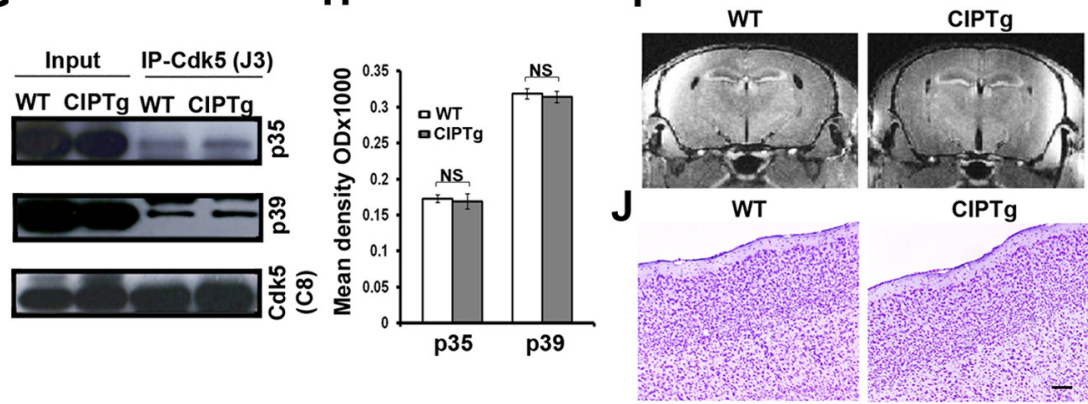

Figure 1. Characterization of CIPTg mice. A, The CIPTg construct contains a $3^{\prime}$-FLAG-tagged CIP transgene incorporated in to the ROSA26 locus whose $5^{\prime}$ regulatory elements were separated from the coding region with a floxed stop sequence. A frt-flanked neomycin resistance (Neo) cassette was inserted next to the transgene before the $3^{\prime}$ homology arm. Representative confocal images of frontal cortex (layer 2/3) (B) and hippocampus (CA3 region) (C) from 6-week-old and 18-week-old WT and CIPTg mice. The sections were immunostained with anti-FLAG antibody (red), and nuclei were counterstained with DAPI (blue). D, Immunoblot analyses of brain lysates from WT and CIPTg mice using anti-Cdk5 (C8) and anti-FLAG antibodies. Equal amounts of protein loading were confirmed by reprobing the membrane with anti-tubulin antibody. $\boldsymbol{E}$, Quantification of immunoblot analyses in $\boldsymbol{D}$ by densitometric scanning $(n=3)\left({ }^{* * *} p<0.001\right.$ and $\left.{ }^{\mathrm{NS}} p>0.05\right)$. $\boldsymbol{F}$, Kinase assays using active kinase (Cdk5) from WT and CIPTg mice brains to phosphorylate a high-molecular-weight neurofilament (NF-H) peptide ( $\left.{ }^{\mathrm{NS}} p>0.05\right)$. G, WT and CIPTg mice brain lysates were immunoprecipitated (IP) using anti-Cdk5 (J3) antibody. Samples were separated by SDS-PAGE and immunoprobed with anti-p35, anti-p39, and anti-Cdk5 (C8) antibodies. $\boldsymbol{H}$, Quantification of immunoblot analyses in $\boldsymbol{G}$ by densitometric scanning $\left({ }^{\mathrm{NS}} p>0.05\right)$. MRI scanning images of coronal slices $(\boldsymbol{I})$ and Nissl staining images of frontal cortex $(J)$ from WT and $(\mathrm{IPTg}$ mice brains. Scale bars, $20 \mu \mathrm{m}$. Data are representative of $n=4$ mice. Error bars indicate \pm SEM.

was cleaned with $70 \%$ ethanol and dried between trials. Novel food was also placed outside of all the arms to minimize the possibility of smell as a cue. During the test phase, mice were placed individually in the center of the maze and subjected to reference and working memory tasks for $10 \mathrm{~d}$, with the same four arms (numbers 2, 4, 6, and 8) baited in each of the trial. The test trial continued until all four baits had been consumed or until $5 \mathrm{~min}$ had elapsed. Measures were made of the number of reference memory errors (entering an arm that was not baited), working memory errors (entering an arm containing food but previously entered), and also the total time taken to finish the task. Mice were given one test session per day, $5 \mathrm{~d}$ /week during the period of behavioral testing. The test and training sessions were performed in the same time of day in a moderately lit room with standard conditions of temperature and free from any stray noise.

Statistics. All values are expressed as the mean of at least three determinations \pm SEM. Data were analyzed by Student's $t$ test, and $p$ value $<0.05$ was considered to indicate statistical significance. For radial maze analyses, working memory errors were plotted by the mice over the entire test sessions averaged and subjected to one-way ANOVA, followed by post hoc Tukey's test. The reference memory errors counted during the test sessions were plotted as bins of $1 \mathrm{~d}$ each and subjected to repeatedmeasures ANOVA, followed by post hoc Tukey's test.

\section{Results}

Generation and characterization of mice overexpressing CIP transgene

We generated CIPTg mice that overexpressed CIP in the forebrain under the control of Camk2a promoter using the Cre/LoxP recombination system. The CIP transgene was tagged with the FLAG epitope (Fig. 1A). To examine the CIP transgene expression pattern in CIPTg mice brain, immunohistochemistry (Fig. $1 B, C$ ) and Western blot analyses (Fig. $1 D$, second panel, $E$ ) were performed on the brain samples of CIPTg and WT control mice using the anti-FLAG antibody. Results confirmed the robust forebrain-specific expression of CIP, which was increased with increasing age in CIPTg mice compared with the WT mice. It has been reported previously that CIP expression does not affect endogenous Cdk5 activity of neurons in vitro (Kesavapany et al., 2007). Hence, we wanted to test the effect of CIP overexpression on endogenous Cdk5 activity in vivo in CIPTg mice using Western blot analyses (Fig. 1D, top panel, E) and kinase assays (Fig. $1 F$ ). We did not observe any significant changes in endogenous Cdk5 activity and expression levels in CIPTg mice compared with WT mice. Coimmunoprecipitation assays were performed to investigate the effect of CIP on the interaction of Cdk5 with its activators p35 and p39 using CIPTg and WT mice brain lysates (Fig. 1G,H). Results showed that the normal Cdk5/p35 or Cdk5/ p39 interactions were not significantly affected by CIP expression in CIPTg mice. To examine further whether CIP overexpression causes any structural changes in CIPTg mice brain, we performed MRI of the mice. The results validate that overall brain morphology and organization in CIP mice appear normal (Fig. 1I). Additionally, Nissl staining showed no changes in cortical patterning 
A
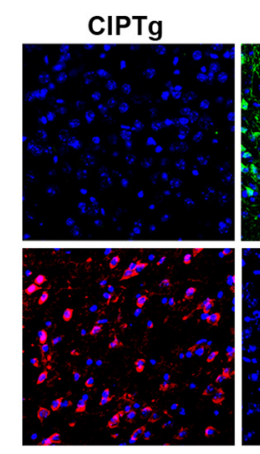

C

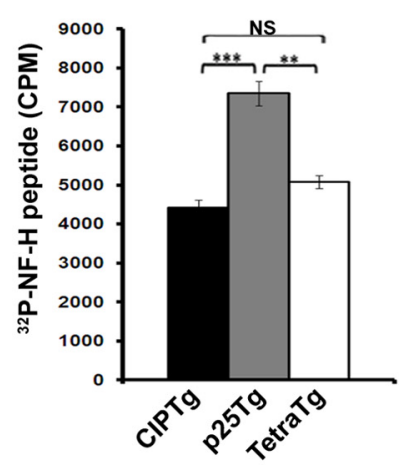

B

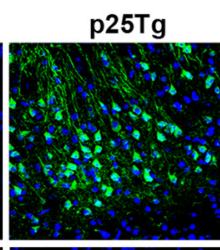
TetraTg
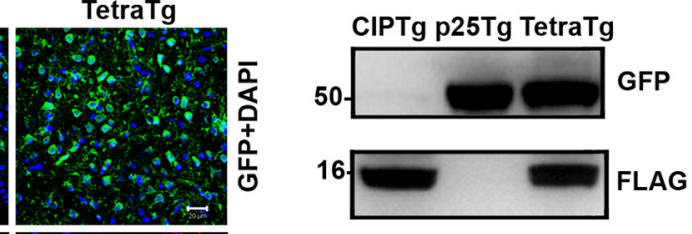

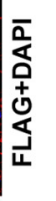

D

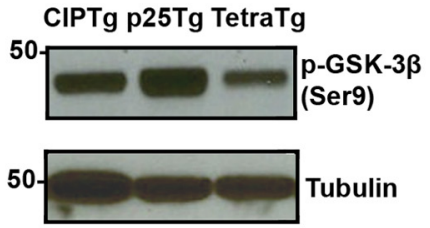

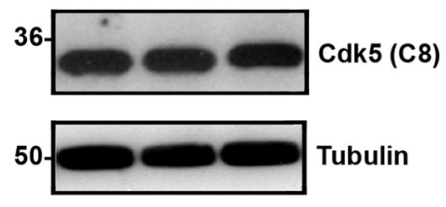

E

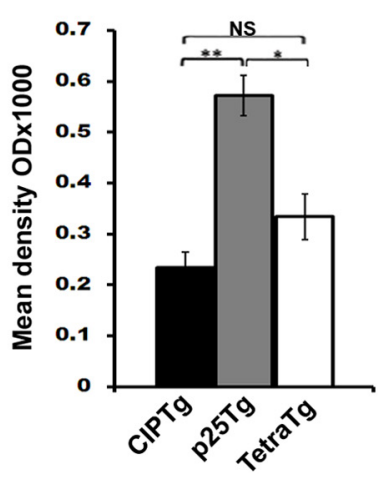

Figure 2. Characterization of TetraTg mice. A, Immunofluorescence images of frontal cortex (layer 2/3) from 12 week induced p25Tg mice, TetraTg, and their respective age-matched CIPTg control mice. The sections were immunostained with anti-GFP antibody (green) and anti-FLAG antibody (red). Nuclei were counterstained with DAPI (blue). $\boldsymbol{B}$, Immunoblot analyses of brain lysates from 12 week induced p25Tg, TetraTg, and the CIPTg mice using anti-GFP, anti-FLAG, and anti-Cdk5 (C8) antibodies. C, Representative in vitro kinase assays using active kinase (Cdk5) immunoprecipitated from the $25 \mathrm{Tg}$, TetraTg, and CIPTg mice ${ }^{* *} p<0.001,{ }^{* * *} p<0.0001$, $\left.{ }^{\text {NS }} p>0.05\right)$. D. Western blot analyses of brain lysates from 12 week induced $p 25 \mathrm{Tg}$, TetraTg, and the CIPTg mice using anti-phospho-GSK-3 $\beta$ (Ser9) antibody. E, Quantification of immunoblots in D by densitometric scanning $\left({ }^{*} p<0.05,{ }^{* *} p<0.001,{ }^{\text {NS }} p>0.05\right)$. Scale bars, $20 \mu \mathrm{m}$. Error bars indicate \pm SEM.

between the mice (Fig. 1J). Together, our results indicate that the endogenous Cdk5 level, activity, and the normal brain development were not affected by CIP overexpression in CIPTg mice.

\section{CIP overexpression specifically inhibits p25/Cdk5} hyperactivation in TetraTg mice

To study the ability of CIP to specifically inhibit the p25/Cdk5 hyperactivation-mediated neurodegeneration in vivo, we generated a TetraTg mouse that overexpresses p 25 and CIP under the direction of the Camk2a promoter. TetraTg mice were generated by crossing the CIPTg mice with the p25/Camk2a bitransgenic mice [p25Tg mice generated by crossing C57BL/6-Tg (tetOCDK5R1/GFP) 337Lht/J (The Jackson Laboratory) mice with B6; CBA-Tg (Camk2a-tTA) 1Mmay/J (The Jackson Laboratory) mice]. Immunohistochemistry and Western blot analyses were performed using anti-GFP and anti-FLAG antibodies to confirm the expression of both $\mathrm{p} 25$ and CIP transgene in the forebrain of the TetraTg mice (Fig. 2A,B). To examine the effect of CIP overexpression on the $\mathrm{p} 25$-mediated Cdk5 hyperactivation, we performed Western blot analyses and in vitro kinase assays on the samples from 12 week induced $\mathrm{p} 25 \mathrm{Tg}$, TetraTg, and age-matched CIPTg mice brains. No significant changes in the Cdk5 expression levels were observed among all the samples (Fig. 2B). However, there was a significant increase in Cdk5 activity in p25Tg mice compared with the CIPTg mice. In contrast, Cdk5 activity was reduced in TetraTg mice compared with the $\mathrm{p} 25 \mathrm{Tg}$ mice (Fig. 2C). Collectively, these results suggest that p25-induced Cdk5 hyperactivation was effectively inhibited by CIP overexpression in TetraTg mice. GSK- $3 \beta$ is another principal kinase thought to phosphorylate tau and involved in neurodegeneration (Ferrer et al., 2002). To study whether CIP expression has any effect on the GSK-3 $\beta$ activity, Western blot analyses were performed on the samples from $\mathrm{p} 25 \mathrm{Tg}$, TetraTg, and CIPTg mice using antiphospho-GSK-3 $\beta$ (Ser9) antibody (Fig. $2 D, E$ ). It has already been proved that GSK- $3 \beta$ activity is negatively regulated by its phosphorylation at serine 9 (Jope and Johnson, 2004). Our results determine that GSK- $3 \beta$ activity was significantly decreased in 25 Tg mice in which, as in TetraTg mice, GSK-3 $\beta$ activity increased to levels similar to control CIPTg mice.

\section{CIP reduces p25/Cdk5-mediated neuroinflammation in TetraTg mice}

We have shown previously that robust neuroinflammation occurred in the p25Tg mice (Sundaram et al., 2012). To examine the effect of CIP expression on p25-mediated astrogliosis and microgliosis, we preformed immunohistochemistry and Western blot analyses using GFAP (marker for astrocytes) and Cd11b (marker for microglia) antibodies on the samples from 12 week induced p25Tg, TetraTg, and age-matched CIPTg mice brains. CIP expression on its own did not induce any astrogliosis and microgliosis. Whereas p25 expression elevated GFAP and Cd11b expression levels in $\mathrm{p} 25 \mathrm{Tg}$ mice, in contrast, astrogliosis and microgliosis were significantly reduced in TetraTg mice compared with p25Tg mice (Fig. 3A-C). We have shown previously that p25/Cdk5 hyperactivation caused cPLA2 upregulation to produce the soluble lipid mediator lysophosphatidylcholine (LPC), which mediated neuroinflammation in p25Tg mice (Sundaram et al., 2012). To investigate the effect of CIP overexpression on 
A

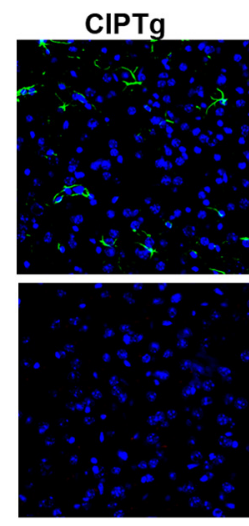

D

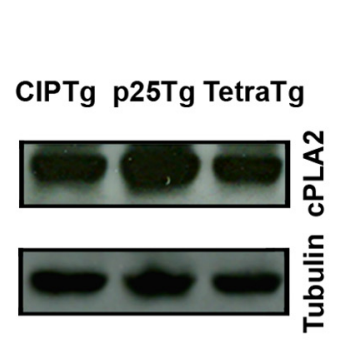

B

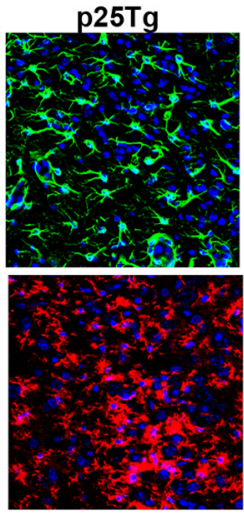

E

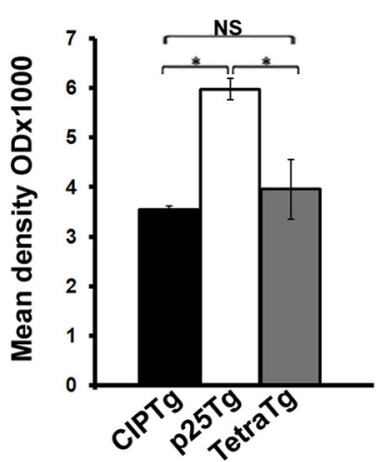
TetraTg

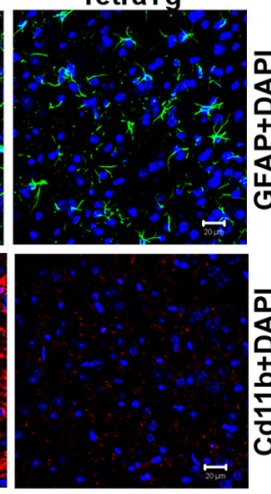

F
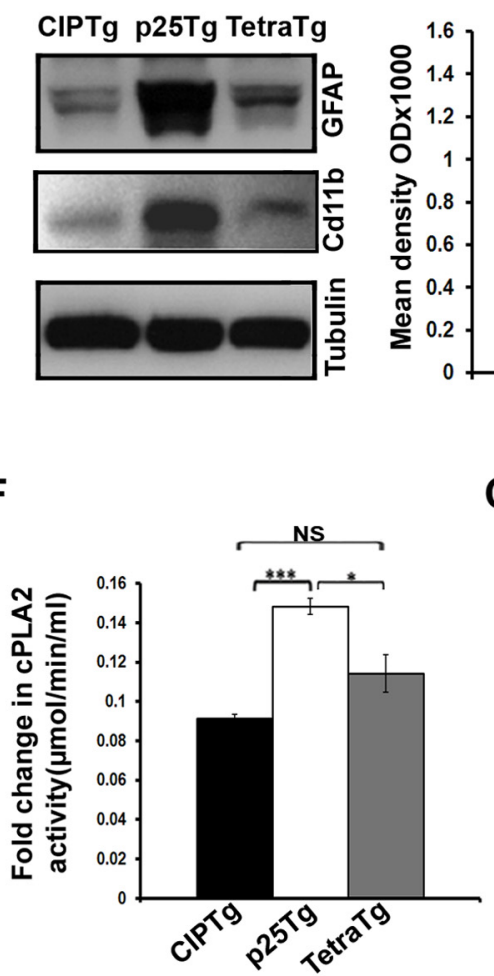

C

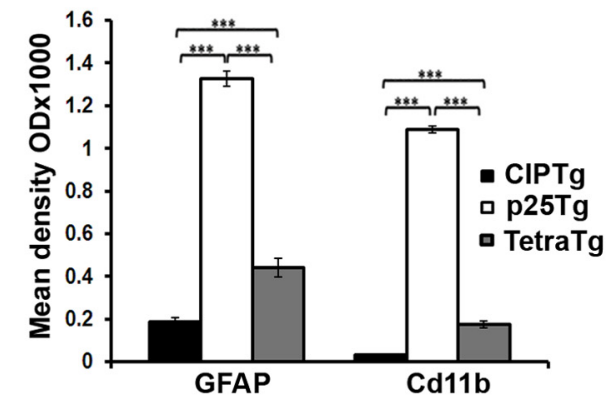

G

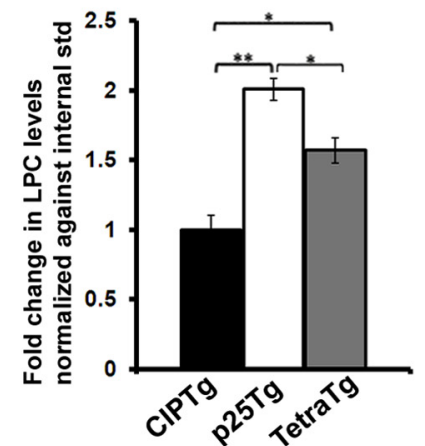

Figure 3. Reduced neuroinflammation in TetraTg mice. $A$, Representative confocal images of frontal cortex from 12 week induced p25Tg, TetraTg, and CIPTg mice. The brain sections were labeled with anti-GFAP antibody (green), anti-Cd11b antibody (red), and nuclei were stained with DAPI (blue). B, Western blot analyses of brain lysates from p25Tg, TetraTg, and the CIPTg mice using anti-GFAP and anti-Cd11b antibodies. C, Quantification of immunoblots in $\boldsymbol{B}$ by densitometric scanning ( $\left.{ }^{* * *} p<0.001\right)$. D, Immunoblot analyses were performed on lysates from the samples same as in $\boldsymbol{B}$ using anti-CPLA2 antibody. $\boldsymbol{E}$, Quantification of immunoblot analyses in $\boldsymbol{D}\left({ }^{*} p<0.05,{ }^{\mathrm{NS}} p>0.05\right)$. $\boldsymbol{F}$, CPLA2 activity assays were performed with lysates from $p 25 \mathrm{Tg}$, TetraTg, and CIPTg mice $\left({ }^{*} p<0.05,{ }^{N S} p>0.05,{ }^{* * *} p<0.001\right)$. G, Results from the mass spectrometric analyses for the $\mathrm{p} 25 \mathrm{Tg}$, TetraTg, and CIPTg mice brain samples. Results were normalized against the internal standards of LPC $\left({ }^{*} p<0.05,{ }^{* *} p<0.01\right)$. Scale bars, $20 \mu \mathrm{m}$. Data are representative of $n=4$ mice. Error bars indicate \pm SEM.

this mechanism, Western blot analyses, cPLA2 activity assays, and mass spectrometry analyses were performed using the brain samples from p25Tg, TetraTg, and CIPTg mice (Fig. 3D-G). Data indicated that p25-mediated CPLA2 upregulation and LPC production were significantly reduced in TetraTg compared with p25Tg mice but not to basal/control levels. Together, our results confirmed that LPC upregulation could be affected in part by CIP expression, but there may be distinct pathways that are responsible for CPLA2 upregulation by $\mathrm{p} 25$ and p25/Cdk5 activity inhibition.

CIP reduces p25/Cdk5-mediated tau phosphorylation and amyloid accumulations in TetraTg mice

Previous studies already proved that CIP can inhibit the p25/ Cdk5 hyperactivation-mediated tau hyperphosphorylation and $\beta$-amyloid accumulation in vitro (Zheng et al., 2005). To confirm this finding in vivo, we performed immunohistochemistry and Western blot analyses using a number of phospho-tau antibodies. We found that there was a reduction in AT8 and AT180 levels in TetraTg mice compared with p25Tg mice (Fig. 4A-C). This was also confirmed with AT100 and AT270 antibodies (data not shown). Our results show that CIP significantly inhibited p25mediated tau hyperphosphorylation in TetraTg mice. To investigate whether the CIP overexpression affects the p25-induced $\beta$-amyloid accumulation in TetraTg mice, immunofluorescence and thioflavin-S staining experiments were performed. Results showed an almost total reduction in $\beta$-amyloid and thioflavin-S staining in TetraTg mice compared with p25Tg mice (Fig. 4D, E, top panel). Additionally, Bielschowsky silver staining results further confirmed our findings (Fig. $4 E$, bottom). Collectively our results showed that CIP effectively reduces the development of p25/Cdk5-mediated tau and amyloid neuropathological hallmarks in vivo.

\section{CIP reduces neuronal apoptosis and forebrain atrophy mediated by $\mathrm{p} 25 / \mathrm{Cdk} 5$}

Gross morphological changes and severe atrophy of the forebrain are prominent features of p25Tg mice (Cruz et al., 2003, 2006; Sundaram et al., 2012). Therefore, we set out to determine the effect of CIP on the p25-mediated neuronal apoptosis in TetraTg mice. We used cleaved caspase-3 expression as a marker of apoptosis (Nicholson et al., 1995). Results from immunohistochemistry and Western blot analyses revealed that caspase- 3 expression was increased fivefold in p25Tg compared with the CIPTg mice. This p25-induced caspase-3 overexpression was almost completely abolished in TetraTg mice (Fig. 5A, bottom, $C, D)$. We performed TUNEL assays as an additional measure of apoptosis, and results confirmed that there was a $75 \%$ increase in the number of TUNEL-positive cells in the brain sections of p25Tg mice compared with the CIPTg mice. However, $<20 \%$ of TUNEL-positive cells was observed in TetraTg mice (Fig. 5A, top, $B$ ). Figure $5 E$ shows the considerable reduction in forebrain size in p25Tg mice compared with CIPTg and TetraTg mice. There was no significant difference in size of the brain of the TetraTg 
A
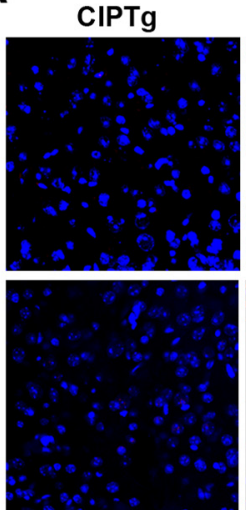

D
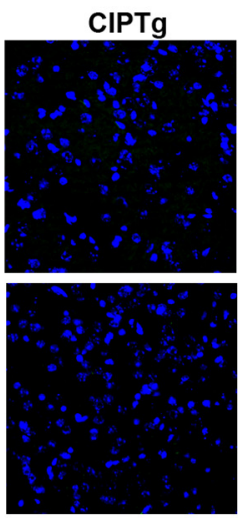

p25Tg
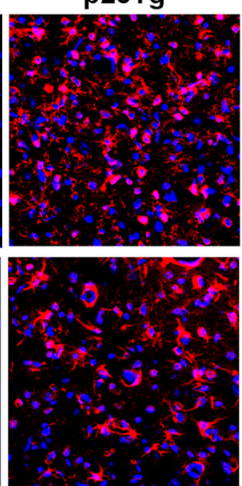

p25Tg
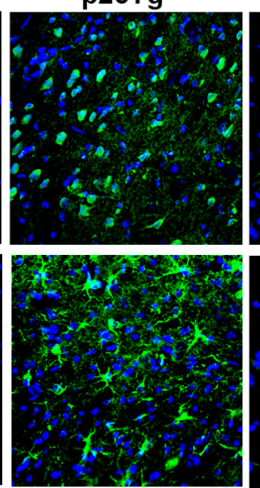

B

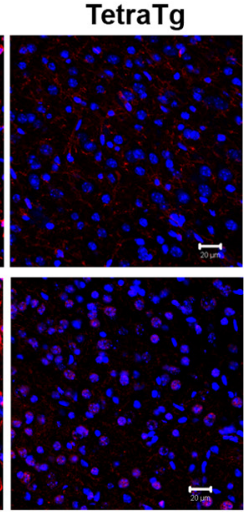

TetraTg
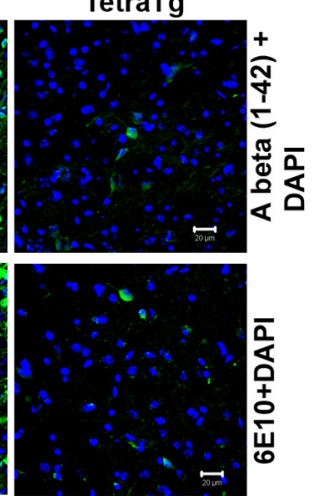

C

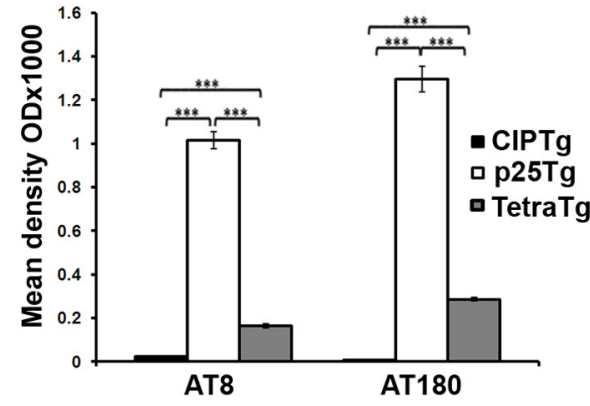

E
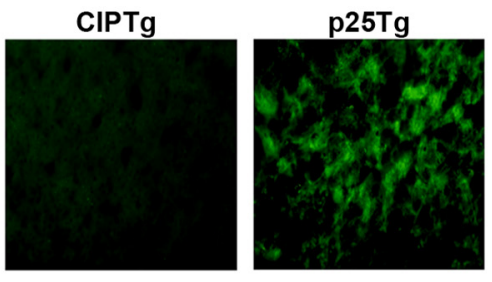

TetraTg
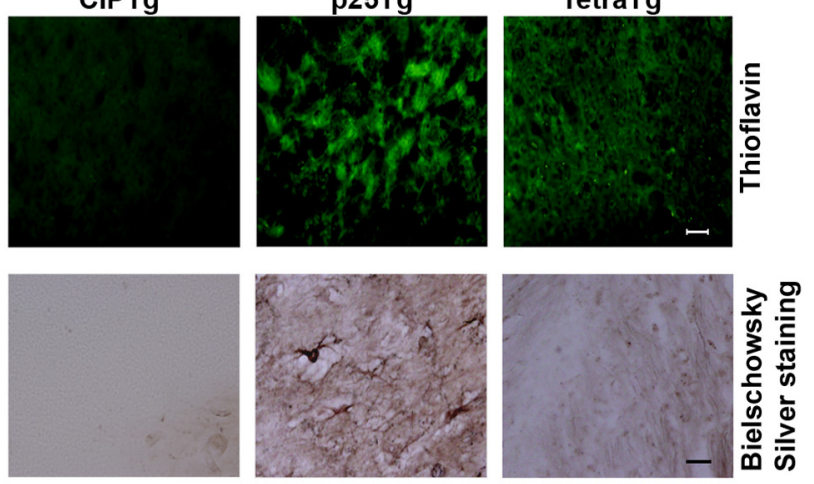

Figure 4. Inhibition of p25-mediated phospho-tau and $\beta$-amyloid accumulation in TetraTg mice. $A$, Immunofluorescence images of frontal cortex from p25Tg, TetraTg, and their respective age-matched (IPTg mice using AT8 (PHF-tau) and AT180 (PHF-tau) (red) antibodies. DAPI-stained nuclei appear blue. B, Hyperphosphorylated tau protein levels were analyzed by Western blot analyses using AT8 and AT180 antibodies. C, Quantification of immunoblots in $\boldsymbol{B}$ by densitometric scanning $\left(^{* * *} p<0.001\right)$. D , Brain sections from p25Tg, TetraTg, and CIPTg mice were immunostained with $A \beta_{1-42}$ and $6 E 10\left(A \beta_{1-16}\right)$ (green). Nuclei were stained with DAPI (blue). $\boldsymbol{E}$, Thioflavin-S staining (top) and Bielschowsky silver staining (bottom) images of the brain sections from p25Tg, TetraTg, and CIPTg mice. Scale bars, $20 \mu \mathrm{m}$. Data are representative of $n=4$ mice. Error bars indicate \pm SEM.

compared with the CIPTg mice. We also determined the gross brain weight of the p25Tg, TetraTg, and CIPTg mice, and the quantification graph in Figure $5 F$ shows that there was a significant reduction in brain weight of the $\mathrm{p} 25 \mathrm{Tg}$ mice compared with CIPTg and TetraTg mice, with no significant difference in the brain weight of the TetraTg mice compared with CIPTg. In summary, our results show that CIP expression rescued against p25induced neuronal apoptosis. To further determine the cortical patterning in TetraTg mice, we performed Nissl histology staining. Severe neuronal patterning deficits were observed in the cortical layers as well as in the hippocampus of the p25Tg mice compared with the CIPTg mice. Cortical and hippocampal patterning were unchanged in TetraTg mice compared with CIPTg mice (Fig. 5G). In vivo brain imaging using MRI on the p25Tg, TetraTg, and CIPTg mice was performed to show cortical shrinkage and cerebral ventricular enlargement in p25Tg mice compared with the CIPTg mice. Significant reductions in p25mediated cortical shrinkage were observed in the TetraTg mice (Fig. $5 H, I$ ). Together, our results provide compelling evidence that CIP expression effectively reduces the p25-mediated forebrain atrophy and neurodegeneration.

\section{CIP expression abolished p25-mediated neurocognitive} deficits in TetraTg mice

We wanted to address the question whether this CIP rescue against neuropathology and apoptosis translates to a benefit in cognitive function. Radial arm maze paradigm showed significant increases in both number of reference and working memory errors in p25Tg mice compared with CIPTg mice. In contrast, TetraTg mice made very few reference and working memory errors compared with p25Tg mice (Fig. 6A,B). Together, our results confirm that TetraTg mice showed superior performance in this spatial memory task compared with the p25Tg mice, clearly demonstrating that CIP hyperexpression reverses the cognitive deficits of p25/Cdk5 hyperactivation in TetraTg mice.

\section{Discussion}

In this study, we show that in vivo expression of CIP, a 125 aa peptide derived from $\mathrm{p} 35$, effectively and specifically inhibits the hyperactivation of $\mathrm{p} 25 / \mathrm{Cdk} 5$. These data are an extension to the in vitro findings detailing CIP protection in primary neurons (Zheng et al., 2005). In addition, this is the first time p25/Cdk5 aberrant hyperactivation has been selectively targeted in vivo. Previous attempts to target Cdk5 activity have not been successful in targeting normal versus aberrant Cdk 5 activity attributable to inhibitors primarily being ATP analogs. This resulted in inhibition of both normal p35/Cdk5 as well as aberrant p25/Cdk5 activities causing neurodevelopmental issues because it is well established that targeting normal p35/Cdk5 activity will result in CNS organizational deficits, synaptic dysfunction, and defects in the migration of neurons (Tsai et al., 1994; Leost et al., 2000; Leclerc et al., 2001). It is therefore critical to selectively target the 
A

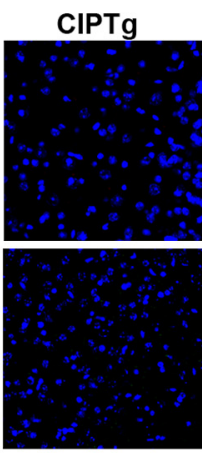

E
B

TetraTg
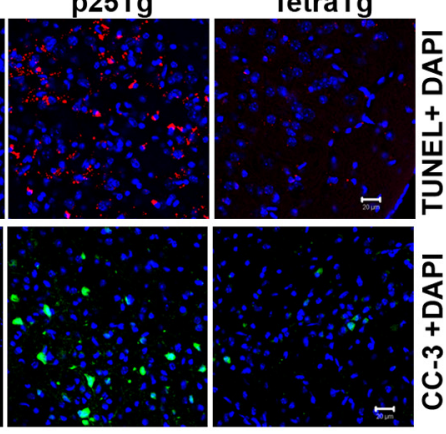

F
C

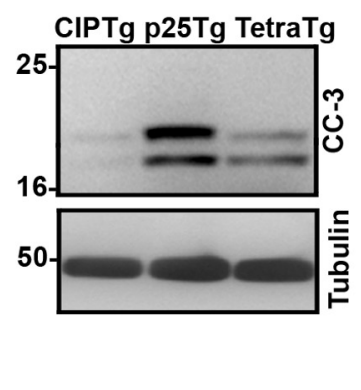

D

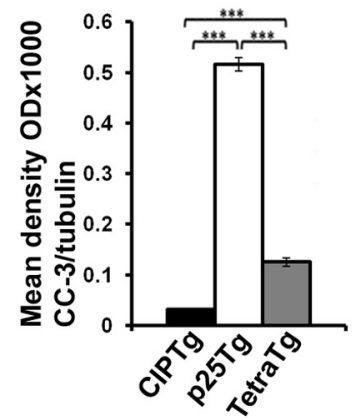

G

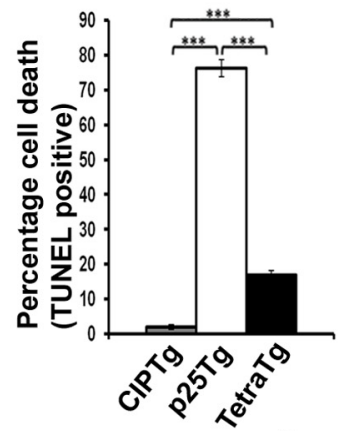

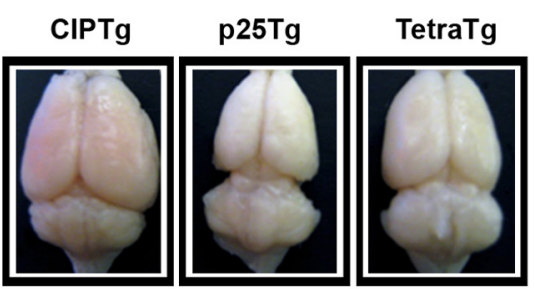

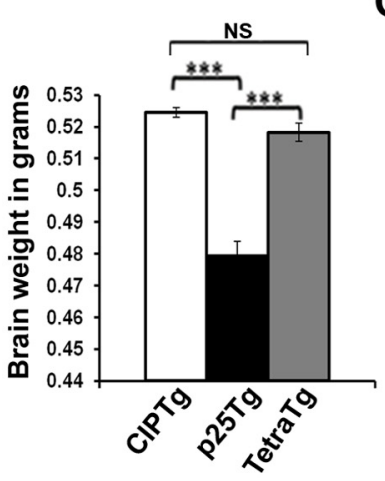

H
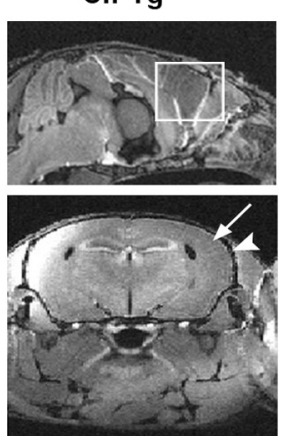

p25Tg
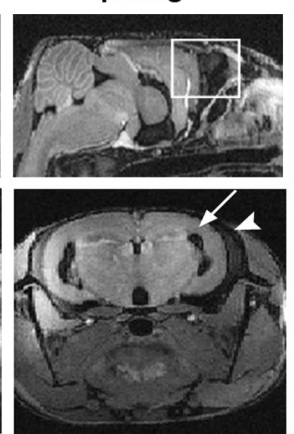

TetraTg
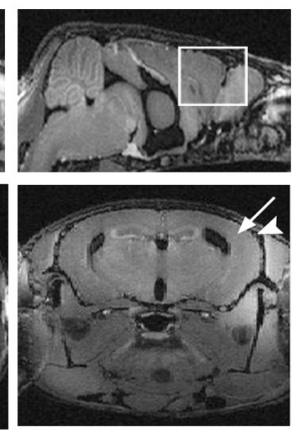

CIPTg

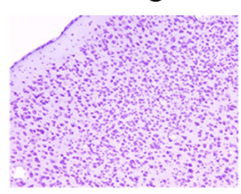

p25Tg
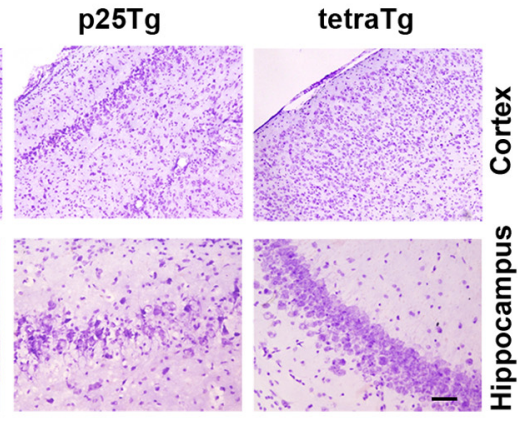

p25Tg

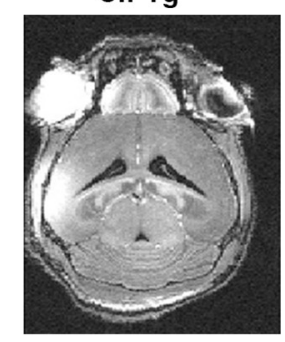

TetraTg

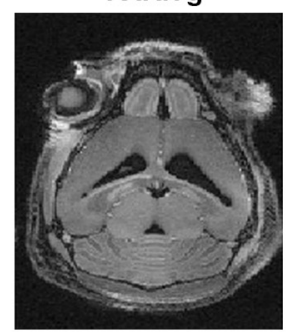

Figure 5. CIP expression rescues p25-induced brain atrophy in TetraTg mice. $A$, Representative confocal images of frontal cortex from 12 week induced p25Tg, TetraTg, and CIPTg mice. Top shows the TUNEL staining images (red), and the bottom shows the immunofluorescence staining with cleaved caspase-3 antibody (green). Nuclei were counterstained with DAPI (blue). $\boldsymbol{B}$, Percentage cell death in bottom of $A$ was calculated by counting the TUNEL-positive cells normalized with DAPI from 10 independent fields $\left({ }^{* * *} p<0.001\right)$. C, Western blot analyses of brain lysates from 12 week induced p25Tg, TetraTg, and (IPTg mice using anti-cleaved caspase-3 antibody. D, Quantification of immunoblots in C by densitometric scanning $\left({ }^{* * *} p<0.001\right)$. $\boldsymbol{E}$, Whole-brain photos showing the levels of forebrain atrophy in CIPTg, p25Tg, and TetraTg mice. F, Quantification of brain weight from p25Tg, TetraTg, and CIPTg mice $\left({ }^{* * *} p<0.0001\right.$ and $\left.{ }^{\mathrm{NS}} p>0.05\right)$. G, Nissl staining images of frontal cortex as well as CA3 region of the hippocampus from the p25Tg, TetraTg, and CIPTg control mice. $\boldsymbol{H}$, I, Representative magnetic resonance images of sagittal, transverse, and axial planes of the CIPTg, p25Tg, and TetraTg mice. White rectangular boxes, arrowheads, and arrows indicate the level of cortical atrophy between the three groups of mice. Scale bars, $20 \mu \mathrm{m}$. Data are representative of $n=4$ mice. Error bars indicate \pm SEM.

aberrantly hyperactive Cdk5 form that causes the pathological hallmarks of tau hyperphosphorylation and amyloid accumulations formed by a neurotoxic or excitotoxic insult in the CNS.

There has been some dispute about the role of p25 in the development of AD-like pathology that has been attributed to differences in tissue collection and preparation protocols (Kerokoski et al., 2001; Takashima et al., 2001; Bian et al., 2002). In our hands and others, we have consistently observed that the overexpression of p25 causes a robust increase in Cdk5 activity leading to phosphorylated tau and neuronal death both in vitro and in vivo (Cruz et al., 2003; Muyllaert et al., 2008; Sundaram et al., 2012). Mechanistically, the formation of p25 is consistent with the well-documented hypothesis of excitotoxicity in neurons undergoing degeneration. Calcium influx, as a result of overactivation of calcium-mediated channels such as NMDARs, activate calpain, which then cleaves a normally membranebound p 35 to generate $\mathrm{p} 25$ that has a longer half-life with a potent Cdk5 hyperactivation profile (Patrick et al., 1999; Lee et al., 2000).

Previous studies identified a central fragment of p35 (residues 154-279), called CIP, that can effectively inhibit Cdk5 activity in vitro (Amin et al., 2002; Zheng et al., 2002). Additional studies identified CIP as a potent, selective inhibitory peptide toward p25/Cdk5 without affecting p35/Cdk5 activity (Zheng et al., 2005). As an extension of these studies and a validation of those findings in vivo, we generated the CIPTg mouse model that was crossed with region-specific Camk2a-Cre mouse to allow CIP expression in the forebrain. These mice constitutively expressed 
A

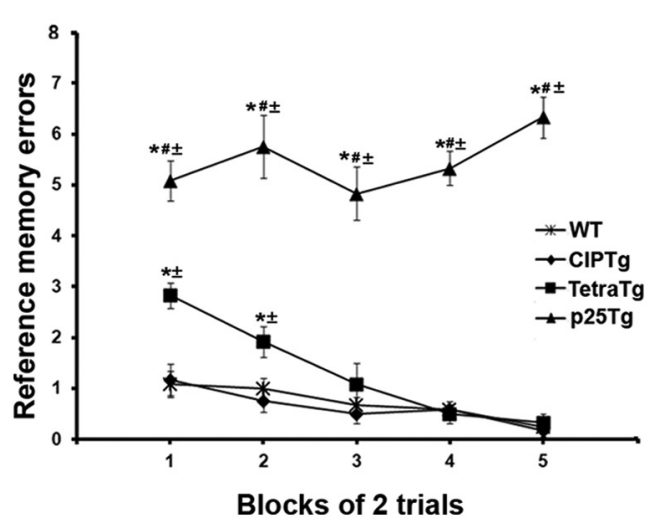

B

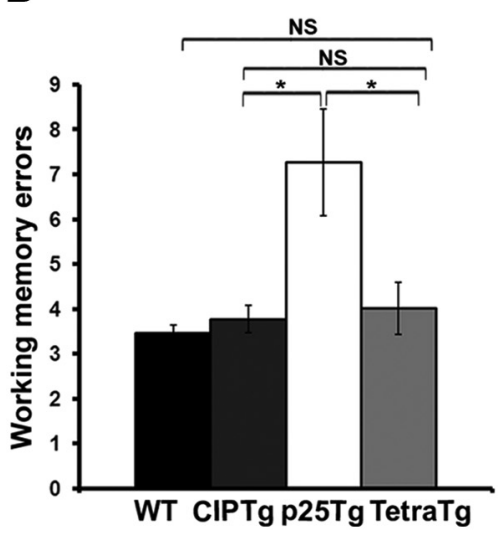

our results indicate that GSK-3 $\beta$ activity in 12 week induced p25Tg mouse was significantly decreased compared with the control mice, therefore suggesting that GSK $-3 \beta$ is actually not responsible for the tau phosphorylation in the p25Tg mice. Additionally, in the TetraTg mice, GSK-3 $\beta$ activity is increased, therefore not correlating with decreased tau phosphorylation.

To ensure that the reductions of $\mathrm{p} 25 /$ Cdk5 activity, phosphorylated tau, and amyloid formation manifested in neuroprotection and cognitive benefit, we used MRI in these mice as well as behavioral cognitive assessments. Together, the overexpression of CIP in the $\mathrm{p} 25 \mathrm{Tg}$ model rescued the cortical atrophy caused by p 25 overexpression and also corrected the cognitive deficits monitored by radial maze study, showing that CIP was responsible for the neuroprotection observed. Obvious extensions to this study is to

CIP under the Camk2a promoter at relatively stable levels, probably attributed to the ROSA26 locus in which the transgene was inserted. Based on previous in vitro evidence, we believed that normal Cdk5 activity would not be affected in the CIPTg mice (Zheng et al., 2005), and our results confirmed that CIPTg mice were phenotypically identical to WT C57BL/6 mice in terms of nervous system development, body weight, and behavior. In addition, normal Cdk5/p35 or Cdk5/p39 interactions were not affected by CIP expression in CIPTg mice. Previously, we extensively characterized the p25Tg mice that were first described to be a robust model that exhibit AD-like neuropathology (Cruz et al., 2003, 2006). We found extensive phosphorylation of tau beginning at 4 weeks, whereas amyloid accumulations were apparent beginning at 8 weeks. We also found neuroinflammation as an early event in the p25Tg mice, occurring only after 1 week of p25 expression induction (Sundaram et al., 2012).

To determine whether CIP could selectively reduce p25/ Cdk5-mediated neuroinflammation and neurodegeneration, we crossed our CIPTg mice with the p25Tg mice to generate the TetraTg mice that overexpress both CIP and p25 in the forebrain. Neuroinflammation was extensively decreased in both microgliotic and astrogliotic paradigms in TetraTg mice. In addition, Cdk5/p25-mediated cPLA2 upregulation and LPC production were markedly reduced in TetraTg mice compared with p25Tg mice. However, LPC levels in TetraTg mice were not reduced to the levels of control CIP mice. This explains why microgliosis/ astrogliosis were not completely abolished in TetraTg mice. The data generated here suggest that CPLA2-mediated neuroinflammation and neurodegeneration, at least in part, function through a distinct mechanism, and CIP-mediated inhibition of $\mathrm{p} 25 / \mathrm{Cdk} 5$ activity may not be sufficient to completely block p25 overexpression-mediated cPLA2 upregulation. Moreover, the hallmark formations of hyperphosphorylated tau and amyloid accumulations were drastically reduced in these mice compared with the $\mathrm{p} 25 \mathrm{Tg}$ mice. Previous reports proved that Cdk5 negatively regulates GSK- $3 \beta$ through the activation of protein phosphatase 1 (Morfini et al., 2004). Besides, studies also suggest that Cdk5/p 25 hyperactivation inhibits GSK-3 $\beta$ activity by enhancing the inhibitory phosphorylation at serine 9 of GSK-3 $\beta$ only in young p25Tg (Plattner et al., 2006; Wen et al., 2008). However, cross the CIPTg with other models in which p25/Cdk5 activity has been found, such as the amyloid precursor protein transgenic and P301L models (Lewis et al., 2000; Yu et al., 2012), which would be an extension of the proof of concept for CIP. The p25Tg model provides an opportunity to study a mechanism-mediated model of neurodegeneration in which aberrant Cdk5 hyperactivation is involved. Increased activation of Cdk5 as well as early onset of neuroinflammation has also been observed in other mouse models that have been used to study disease (Oakley et al., 2006; Yu et al., 2012).

Additionally, the CIP model may be of potential use in nonCNS indications in which Cdk5 activity has been implicated, such as pancreatic $\beta$ cells and involvement in diabetes (Daval et al., 2011). Progression of CIP studies has identified a smaller 24 aa peptide derived by serial truncation of CIP. This 25 aa peptide (termed as P5) has been shown to inhibit p25/Cdk5 activity in transfected HEK cells as well as transduced primary neurons, but in vivo studies are ongoing now (Zheng et al., 2010). The possibility of these peptides, CIP and P5, generating information about a selective small molecule inhibitor is low, but the use of these molecules in a biologics manner in vivo is a definite possibility. Additionally, in the quest to find a small molecule inhibitor in the mold of CIP and P5, encoded ligand technology can be used to identify compounds that mimic a P5 and CIP binding to Cdk5.

Using the collective data from the specific inhibition from CIP in the presence of p25 in TetraTg mice will afford better understanding of Cdk5 hyperactivation in neurodegeneration. The knowledge gained from our study will develop possible strategies to produce a specific $\mathrm{p} 25 / \mathrm{Cdk} 5$ inhibitor that will reduce pathology in neurodegenerative diseases in which aberrant Cdk5 activity caused by the formation of p 25 has been implicated in the disease process.

\section{References}

Ahlijanian MK, Barrezueta NX, Williams RD, Jakowski A, Kowsz KP, McCarthy S, Coskran T, Carlo A, Seymour PA, Burkhardt JE, Nelson RB, McNeish JD (2000) Hyperphosphorylated tau and neurofilament and cytoskeletal disruptions in mice overexpressing human p25, an activator of cdk5. Proc Natl Acad Sci U S A 97:2910-2915. CrossRef Medline

Amin ND, Albers W, Pant HC (2002) Cyclin-dependent kinase 5 (cdk5) 
activation requires interaction with three domains of p35. J Neurosci Res 67:354-362. CrossRef Medline

Aoki I, Wu YJ, Silva AC, Lynch RM, Koretsky AP (2004) In vivo detection of neuroarchitecture in the rodent brain using manganese-enhanced MRI. Neuroimage 22:1046-1059. CrossRef Medline

Bian F, Nath R, Sobocinski G, Booher RN, Lipinski WJ, Callahan MJ, Pack A, Wang KK, Walker LC (2002) Axonopathy, tau abnormalities, and dyskinesia, but no neurofibrillary tangles in p25-transgenic mice. J Comp Neurol 446:257-266. CrossRef Medline

Chuang KH, Koretsky A (2006) Improved neuronal tract tracing using manganese enhanced magnetic resonance imaging with fast $\mathrm{T}(1)$ mapping. Magn Reson Med 55:604-611. CrossRef Medline

Cruz JC, Tsai LH (2004) Cdk5 deregulation in the pathogenesis of Alzheimer's disease. Trends Mol Med 10:452-458. CrossRef Medline

Cruz JC, Tseng HC, Goldman JA, Shih H, Tsai LH (2003) Aberrant Cdk5 activation by $\mathrm{p} 25$ triggers pathological events leading to neurodegeneration and neurofibrillary tangles. Neuron 40:471-483. CrossRef Medline

Cruz JC, Kim D, Moy LY, Dobbin MM, Sun X, Bronson RT, Tsai LH (2006) p25/cyclin-dependent kinase 5 induces production and intraneuronal accumulation of amyloid $\beta$ in vivo. J Neurosci 26:10536-10541. CrossRef Medline

Daval M, Gurlo T, Costes S, Huang CJ, Butler PC (2011) Cyclin-dependent kinase 5 promotes pancreatic beta-cell survival via Fak-Akt signaling pathways. Diabetes 60:1186-1197. CrossRef Medline

Dhavan R, Tsai LH (2001) A decade of CDK5. Nat Rev Mol Cell Biol 2:749759. CrossRef Medline

Ferrer I, Barrachina M, Puig B (2002) Glycogen synthase kinase-3 is associated with neuronal and glial hyperphosphorylated tau deposits in Alzheimer's disease, Pick's disease, progressive supranuclear palsy and corticobasal degeneration. Acta Neuropathol 104:583-591. CrossRef Medline

Jope RS, Johnson GV (2004) The glamour and gloom of glycogen synthase kinase-3. Trends Biochem Sci 29:95-102. CrossRef Medline

Kerokoski P, Suuronen T, Salminen A, Soininen H, Pirttil ä T (2001) The levels of $\mathrm{cdk} 5$ and $\mathrm{p} 35$ proteins and tau phosphorylation are reduced during neuronal apoptosis. Biochem Biophys Res Commun 280:9981002. CrossRef Medline

Kesavapany S, Li BS, Amin N, Zheng YL, Grant P, Pant HC (2004) Neuronal cyclin-dependent kinase 5: role in nervous system function and its specific inhibition by the Cdk5 inhibitory peptide. Biochim Biophys Acta 1697: 143-153. CrossRef Medline

Kesavapany S, Zheng YL, Amin N, Pant HC (2007) Peptides derived from Cdk5 activator p35, specifically inhibit deregulated activity of Cdk5. Biotechnol J 2:978-987. CrossRef Medline

Lau LF, Seymour PA, Sanner MA, Schachter JB (2002) Cdk5 as a drug target for the treatment of Alzheimer's disease. J Mol Neurosci 19:267-273. CrossRef Medline

Leclerc S, Garnier M, Hoessel R, Marko D, Bibb JA, Snyder GL, Greengard P, Biernat J, Wu YZ, Mandelkow EM, Eisenbrand G, Meijer L (2001) Indirubins inhibit glycogen synthase kinase- 3 beta and CDK5/p25, two protein kinases involved in abnormal tau phosphorylation in Alzheimer's disease. A property common to most cyclin-dependent kinase inhibitors? J Biol Chem 276:251-260. CrossRef Medline

Lee MS, Kwon YT, Li M, Peng J, Friedlander RM, Tsai LH (2000) Neurotoxicity induces cleavage of p35 to p25 by calpain. Nature 405:360-364. CrossRef Medline

Leost M, Schultz C, Link A, Wu YZ, Biernat J, Mandelkow EM, Bibb JA, Snyder GL, Greengard P, Zaharevitz DW, Gussio R, Senderowicz AM, Sausville EA, Kunick C, Meijer L (2000) Paullones are potent inhibitors of glycogen synthase kinase-3beta and cyclin-dependent kinase 5/p25. Eur J Biochem 267:5983-5994. CrossRef Medline

Lewis J, McGowan E, Rockwood J, Melrose H, Nacharaju P, Van Slegtenhorst M, Gwinn-Hardy K, Paul Murphy M, Baker M, Yu X, Duff K, Hardy J, Corral A, Lin WL, Yen SH, Dickson DW, Davies P, Hutton M (2000) Neurofibrillary tangles, amyotrophy and progressive motor disturbance in mice expressing mutant (P301L) tau protein. Nat Genet 25:402-405. CrossRef Medline

Litchfield S, Nagy Z (2001) New temperature modification makes the Bielschowsky silver stain reproducible. Acta Neuropathol 101:17-21. CrossRef Medline

Morfini G, Szebenyi G, Brown H, Pant HC, Pigino G, DeBoer S, Beffert U, Brady ST (2004) A novel CDK5-dependent pathway for regulating
GSK3 activity and kinesin-driven motility in neurons. EMBO J 23:22352245. CrossRef Medline

Muyllaert D, Terwel D, Kremer A, Sennvik K, Borghgraef P, Devijver H, Dewachter I, Van Leuven F (2008) Neurodegeneration and neuroinflammation in cdk5/p25-inducible mice: a model for hippocampal sclerosis and neocortical degeneration. Am J Pathol 172:470-485. CrossRef Medline

Nath R, Davis M, Probert AW, Kupina NC, Ren X, Schielke GP, Wang KK (2000) Processing of cdk5 activator p35 to its truncated form (p25) by calpain in acutely injured neuronal cells. Biochem Biophys Res Commun 274:16-21. CrossRef Medline

Nguyen MD, Julien JP (2003) Cyclin-dependent kinase 5 in amyotrophic lateral sclerosis. Neurosignals 12:215-220. CrossRef Medline

Nicholson DW, Ali A, Thornberry NA, Vaillancourt JP, Ding CK, Gallant M, Gareau Y, Griffin PR, Labelle M, Lazebnik YA, Munday NA, Raju SM, Smulson ME, Yamin TT, Yu VL, Miller DK (1995) Identification and inhibition of the ICE/CED-3 protease necessary for mammalian apoptosis. Nature 376:37-43. CrossRef Medline

Noble W, Olm V, Takata K, Casey E, Mary O, Meyerson J, Gaynor K, LaFrancois J, Wang L, Kondo T, Davies P, Burns M, Veeranna, Nixon R, Dickson D, Matsuoka Y, Ahlijanian M, Lau LF, Duff K (2003) Cdk5 is a key factor in tau aggregation and tangle formation in vivo. Neuron 38:555-565. CrossRef Medline

Oakley H, Cole SL, Logan S, Maus E, Shao P, Craft J, Guillozet-Bongaarts A, Ohno M, Disterhoft J, Van Eldik L, Berry R, Vassar R (2006) Intraneuronal beta-amyloid aggregates, neurodegeneration, and neuron loss in transgenic mice with five familial Alzheimer's disease mutations: potential factors in amyloid plaque formation. J Neurosci 26:10129-10140. CrossRef Medline

Otth C, Concha II, Arendt T, Stieler J, Schliebs R, González-Billault C, Maccioni RB (2002) AbetaPP induces cdk5-dependent tau hyperphosphorylation in transgenic mice Tg2576. J Alzheimers Dis 4:417-430. Medline

Patrick GN, Zukerberg L, Nikolic M, de la Monte S, Dikkes P, Tsai LH (1999) Conversion of p 35 to p25 deregulates Cdk5 activity and promotes neurodegeneration. Nature 402:615-622. CrossRef Medline

Plattner F, Angelo M, Giese KP (2006) The roles of cyclin-dependent kinase 5 and glycogen synthase kinase 3 in tau hyperphosphorylation. J Biol Chem 281:25457-25465. CrossRef Medline

Poore CP, Sundaram JR, Pareek TK, Fu A, Amin N, Mohamed NE, Zheng YL, Goh AX, Lai MK, Ip NY, Pant HC, Kesavapany S (2010) Cdk5-mediated phosphorylation of delta-catenin regulates its localization and GluR2mediated synaptic activity. J Neurosci 30:8457-8467. CrossRef Medline

Saito T, Konno T, Hosokawa T, Asada A, Ishiguro K, Hisanaga S (2007) p25/cyclin-dependent kinase 5 promotes the progression of cell death in nucleus of endoplasmic reticulum-stressed neurons. J Neurochem 102: 133-140. CrossRef Medline

Schmitt WB, Deacon RM, Seeburg PH, Rawlins JN, Bannerman DM (2003) A within-subjects, within-task demonstration of intact spatial reference memory and impaired spatial working memory in glutamate receptor-Adeficient mice. J Neurosci 23:3953-3959. Medline

Smith PD, Crocker SJ, Jackson-Lewis V, Jordan-Sciutto KL, Hayley S, Mount MP, O’Hare MJ, Callaghan S, Slack RS, Przedborski S, Anisman H, Park DS (2003) Cyclin-dependent kinase 5 is a mediator of dopaminergic neuron loss in a mouse model of Parkinson's disease. Proc Natl Acad Sci U S A 100:13650-13655. CrossRef Medline

Sun A, Nguyen XV, Bing G (2002) Comparative analysis of an improved thioflavin-s stain, Gallyas silver stain, and immunohistochemistry for neurofibrillary tangle demonstration on the same sections. J Histochem Cytochem 50:463-472. CrossRef Medline

Sundaram JR, Chan ES, Poore CP, Pareek TK, Cheong WF, Shui G, Tang N, Low CM, Wenk MR, Kesavapany S (2012) Cdk5/p25-induced cytosolic PLA2-mediated lysophosphatidylcholine production regulates neuroinflammation and triggers neurodegeneration. J Neurosci 32: 1020-1034. CrossRef Medline

Takashima A, Murayama M, Yasutake K, Takahashi H, Yokoyama M, Ishiguro K (2001) Involvement of cyclin dependent kinase5 activator p25 on tau phosphorylation in mouse brain. Neurosci Lett 306:37-40. CrossRef Medline

Tandon A, Yu H, Wang L, Rogaeva E, Sato C, Chishti MA, Kawarai T, Hasegawa H, Chen F, Davies P, Fraser PE, Westaway D, St George-Hyslop PH (2003) Brain levels of CDK5 activator p25 are not increased in Alzhei- 
mer's or other neurodegenerative diseases with neurofibrillary tangles. J Neurochem 86:572-581. CrossRef Medline

Town T, Zolton J, Shaffner R, Schnell B, Crescentini R, Wu Y, Zeng J, DelleDonne A, Obregon D, Tan J, Mullan M (2002) p35/Cdk5 pathway mediates soluble amyloid-beta peptide-induced tau phosphorylation in vitro. J Neurosci Res 69:362-372. CrossRef Medline

Tsai LH, Delalle I, Caviness VS Jr, Chae T, Harlow E (1994) p35 is a neuralspecific regulatory subunit of cyclin-dependent kinase 5. Nature 371: 419-423. CrossRef Medline

Wen Y, Planel E, Herman M, Figueroa HY, Wang L, Liu L, Lau LF, Yu WH, Duff KE (2008) Interplay between cyclin-dependent kinase 5 and glycogen synthase kinase $3 \beta$ mediated by neuregulin signaling leads to differential effects on tau phosphorylation and amyloid precursor protein processing. J Neurosci 28:2624-2632. CrossRef Medline

Yoo BC, Lubec G (2001) p25 protein in neurodegeneration. Nature 411: 763-764; discussion 764-765. CrossRef Medline

Yu D, Corbett B, Yan Y, Zhang GX, Reinhart P, Cho SJ, Chin J (2012) Early cerebrovascular inflammation in a transgenic mouse model of Alzheimer's disease. Neurobiol Aging 33:2942-2947. CrossRef Medline
Zheng YL, Li BS, Amin ND, Albers W, Pant HC (2002) A peptide derived from cyclin-dependent kinase activator (p35) specifically inhibits Cdk5 activity and phosphorylation of tau protein in transfected cells. Eur J Biochem 269:4427-4434. CrossRef Medline

Zheng YL, Kesavapany S, Gravell M, Hamilton RS, Schubert M, Amin N, Albers W, Grant P, Pant HC (2005) A Cdk5 inhibitory peptide reduces tau hyperphosphorylation and apoptosis in neurons. EMBO J 24:209-220. CrossRef Medline

Zheng YL, Amin ND, Hu YF, Rudrabhatla P, Shukla V, Kanungo J, Kesavapany S, Grant P, Albers W, Pant HC (2010) A 24-residue peptide (p5), derived from $\mathrm{p} 35$, the Cdk5 neuronal activator, specifically inhibits Cdk5-p25 hyperactivity and tau hyperphosphorylation. J Biol Chem 285: 34202-34212. CrossRef Medline

Zou LB, Yamada K, Tanaka T, Kameyama T, Nabeshima T (1998) Nitric oxide synthase inhibitors impair reference memory formation in a radial arm maze task in rats. Neuropharmacology 37:323-330. CrossRef Medline 